\title{
Examples of Unsustainable Tourism in Middle East
}

\author{
Arash Riasi \\ Institute for Financial Services Analytics, University of Delaware \\ Apt. West 23, 97 Amstel Ave., Newark, DE, USA, 19711 \\ Tel: 302-898-6249Ｅmail: riasi@udel.edu \\ Shirin Pourmiri \\ Department of Physics and Astronomy, University of Delaware \\ Tel: 302-513-3857Ｅmail: pourmiri@udel.edu
}

Received: December 11, 2015 Accepted: December 27, 2015

doi:10.5296/emsd.v5i1.8705 URL: http://dx.doi.org/10.5296/emsd.v5i1.8705

\begin{abstract}
Tourism industry is growing at phenomenal rates and in most cases this growth is associated with irreversible damages to the environment and tourist attractions. It is crucial for the tourism industry to grow sustainably in order to reduce these adverse effects. This paper tries to introduce different examples of unsustainable expansion of tourism industry and the effects of these activities on environment and tourist attractions. The paper discusses disparate examples ranging from natural tourist attractions to historical tourist attractions.
\end{abstract}

Keywords: Sustainable Tourism, Sustainable Development, Tourism Industry, Unsustainable Expansion of Tourism, Environmental Impacts of Tourism.

\section{Introduction}

Tourism industry is an increasingly important source of income, employment and wealth for many countries, but its rapid expansion might have destructive effects on environment (Neto, 2003). One of the major subsections of tourism industry is ecotourism which is defined as responsible travel to natural areas that conserves the environment and improves the well-being of local people (The International Ecotourism Society, 1990). Although ecotourism has many benefits particularly for the economy of remote areas (Das \& Chatterjee, 2015; Holland et al., 2003; Riasi \& Pourmiri, 2015), some critics believe that it can have detrimental impacts on the environment (Das \& Chatterjee, 2015). Therefore, many authors suggest that tourism industry in general, has to grow sustainably and environmental issues 
should be taken into consideration very carefully (Balmford et al., 2002; Holden, 2003; Mihalic, 2000; Riasi \& Pourmiri, 2015; Sharpley, 2000; Tepelus \& Cordobci, 2005). The World Tourism Organization (UNWTO) and United Nations Environment Program (UNEP) (2005) define sustainable tourism as: "Tourism that takes full account of its current and future economic, social and environmental impacts, addressing the needs of visitors, the industry, the environment and host communities". The interrelation between visitors and host communities with natural environment is critical to achieve sustainable development in tourism industry (Walter \& Reimer, 2012). In recent years, countries that rely on tourism industry as their source of income have become more concerned with the environmental problems associated with unsustainable tourism, therefore the need for promoting sustainable tourism development in order to minimize the negative environmental impacts of tourism has become an important topic (Neto, 2003). In this photo essay, various issues related to the sustainable tourism in three Middle Eastern countries (Iran, Turkey, and the United Arab Emirates) are discussed and relevant photos are displayed. All photos are taken by the authors from 2006 to 2015.

\section{Tourism Industry in Iran}

Iran's economy relies heavily on crude oil exports and the country is trying to find alternatives for this source of revenue in order to reduce its dependence on oil exports (Amiri Aghdaie et al., 2012; Riasi, 2015a; Riasi, 2015b; Riasi \& Amiri Aghdaie, 2013; Riasi \& Asadzadeh, 2015). Since Iran has numerous historical and natural tourist attractions, one of the best potential alternatives for reducing the reliance on oil exports is the expansion of the tourism industry (Riasi \& Pourmiri, 2015). It is highly important that this development in tourism industry will not be harmful for the environment, otherwise, it might cause severe problems. In other words, the Iranian tourism industry should expand sustainably (Riasi \& Pourmiri, 2015). According to the World Travel \& Tourism Council (WTTC) (2015a), the direct contribution of travel and tourism industry to Iran's GDP was IRR 237121 billion (approximately USD 9.1 billion) (2.3\% of total GDP) in 2014 and it is expected to rise to IRR 442156 billion (approximately USD 17 billion) (2.9\% of total GDP) by 2025. The total contribution of travel and tourism industry to Iran's GDP was IRR 651511 billion (approximately USD 25.1 billion) (6.3\% of GDP) in 2014. Also in 2014, the travel and tourism industry directly supported 413000 jobs (1.8\% of total employment) in Iran which is expected to rise to 656000 jobs (2.2\% of total employment) by 2025 (WTTC, 2015a). In this section, we will discuss issues related to sustainable tourism in Kish Island, Namak Abrud, and Lake Urmia, which are three popular tourist destinations in Iran.

Kish Island is a 91.5 square kilometer (35.3 square mile) resort island located in the Persian Gulf. The island is a free trade zone and is famous for its numerous shopping centers (Riasi, 2004). The island's population is approximately 26000 according to 2010 census. In recent years, as more people consider Kish Island as their travel destination, the speed of construction of new hotels, shopping centers, and touristic piers in the island has been increased. However, Kish Island is a small island and can serve only a limited number of tourists at any time. It is estimated that the island can serve around 1 million visitors annually, based on the number of hotels, flights, and other infrastructures. Unfortunately the recent 
constructions in this island disregard many environmental issues. Construction of more hotels in Kish can endanger the island's wildlife. Also as the number of hotels and touristic resorts increase, the island will probably have problems in providing fresh water for tourists in near future (Riasi, 2004). Another issue which is very likely to become troublesome for the island is dealing with increasing amounts of wastes produced by tourists as a result of the expansion of touristic resorts. An important step toward solving these environmental problems is to adopt a comprehensive long-term strategy for sustainable development in the island's tourism industry which is the primary source of revenue for the island and its residents.

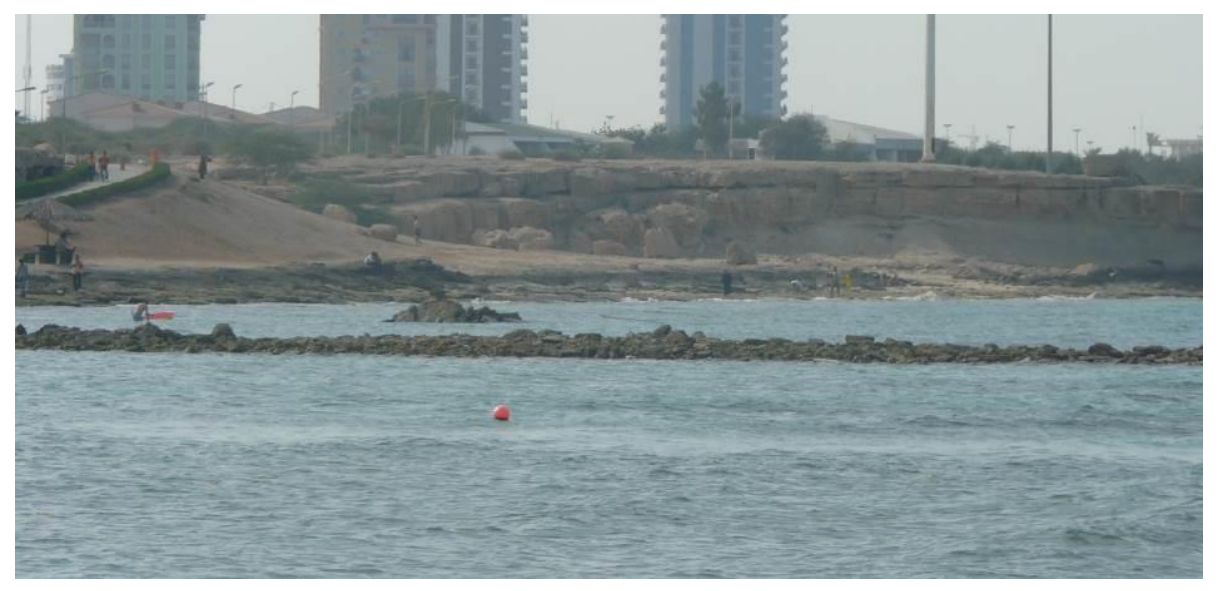

Figure 1. Construction of hotels, shopping centers and touristic piers on the coast of Kish Island, Iran. Kish Island is located in the Persian Gulf and there are many coral reefs along its coast.

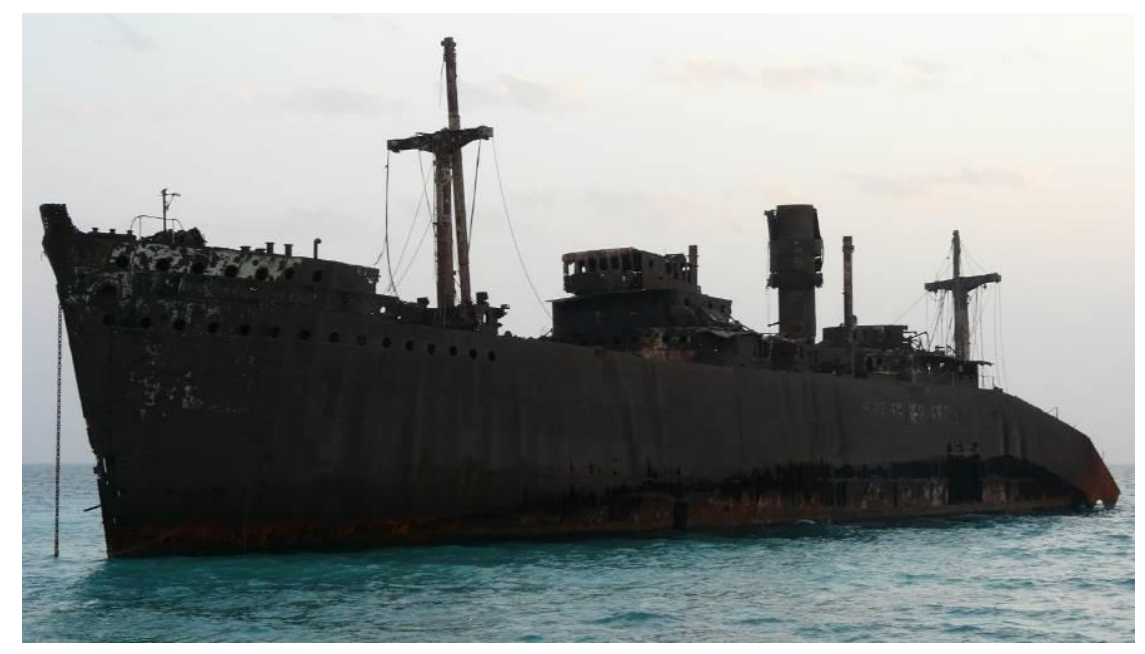

Figure 2. "Greek Ship" is the nickname of the cargo steamship, "Khoula F" which has been beached on the southwest coast of Kish Island, Iran, since 1966. Greek Ship is one of the tourist attractions of Kish Island which has not been well preserved. Experts believe that if the ship wreck will not be preserved, it can cause damages to the nearby coral reefs and it will be eventually sunk. According to Dr. Ali Asghar Mounesan, the Managing Director of

Kish Free Zone Organization, it is very costly to preserve the Greek Ship from further destruction (Hamshahri Newspaper, 2015). 


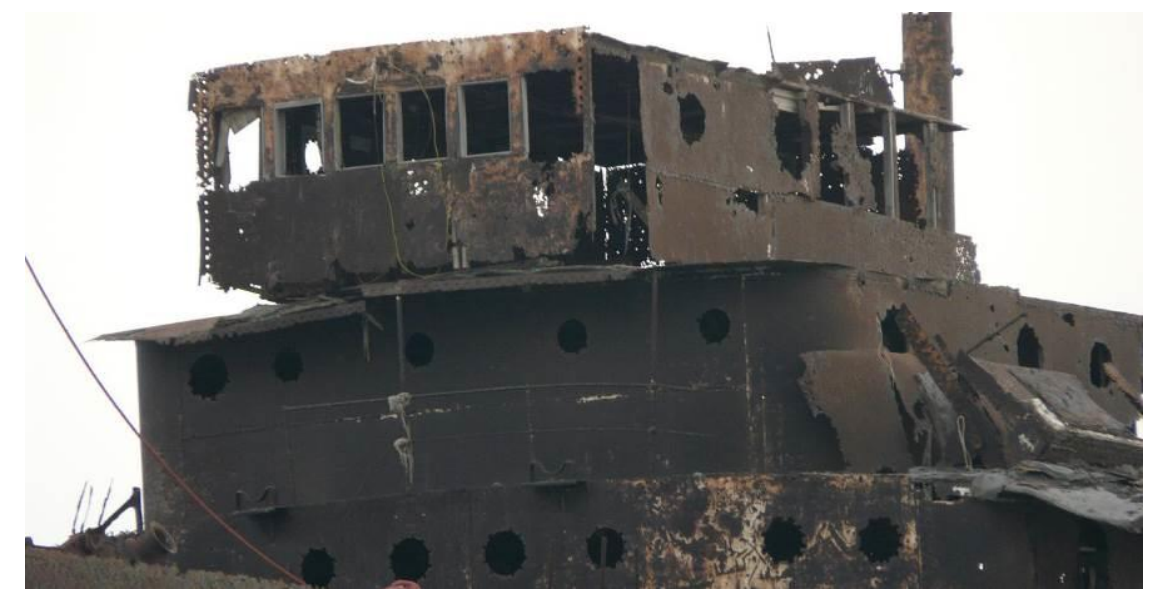

Figure 3. The Greek Ship is severely in danger and needs to be preserved very soon. The ship itself could be an artificial reef and thus be beneficial for the environment if it will be well preserved.

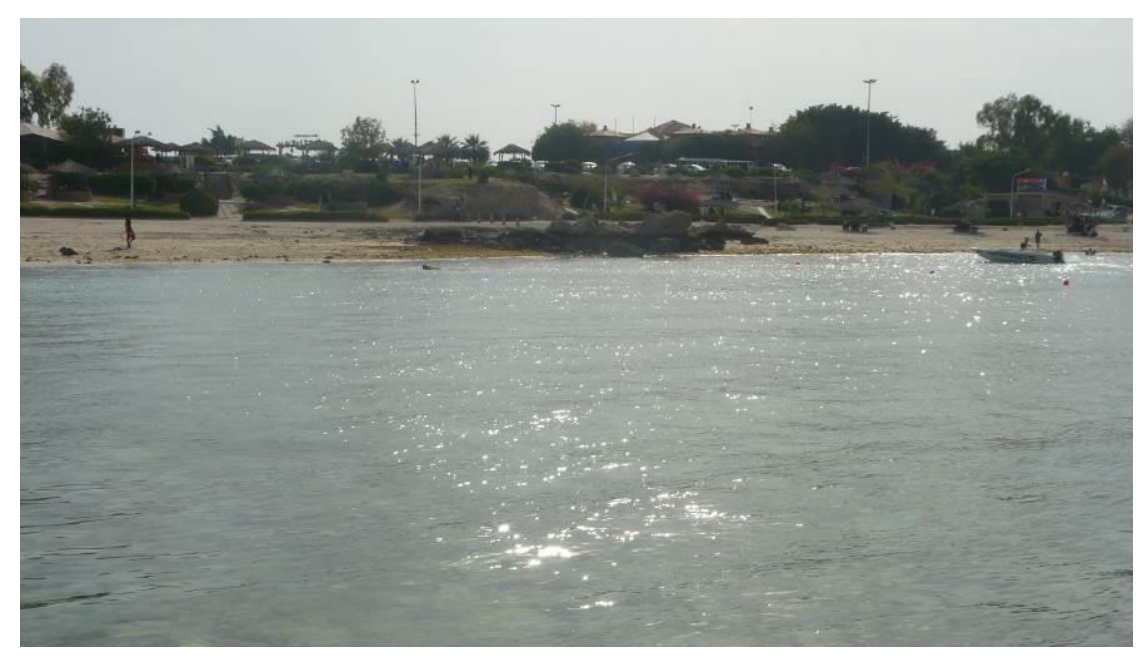

Figure 4. A shopping mall and a coastal park in Kish Island. Some shopping malls in Kish Island are built very close to the water and in many cases dispose their wastewater into the Persian Gulf which is very dangerous for the aquatic animals.

Namak Abrud is a small touristic village in Northern Iran. It has Caspian Sea on its north and Alborz Mountains on its south. There are two separate cable car routes, an amusement park, gift and souvenir shops, numerous villas, hotels, restaurants and coffee shops in this touristic village (Riasi, 2004). Thousands of domestic and foreign tourists visit Namak Abrud every year and this touristic village is trying to expand its facilities and tourist attractions in order to serve more tourists. The rapid expansion of this tourist destination might cause some environmental problems. For instance building new restaurants, villas, and hotels requires cutting more trees. In the past, building the cable car routes in Namak Abrud required cutting lots of trees and made permanent environmental damages. After the cable car routes were constructed, more restaurants and coffee shops were built on the top of the mountain which clearly endangered the wildlife and increased the amount of $\mathrm{CO}_{2}$ emission. As an alternative to the construction of cable car routes, they could have built other tourist attractions like zip 


\section{Macrothink}

lines, hiking trails, or mountain bike trails which cause less severe environmental damages and require cutting fewer trees. It is evident that the expansion of this touristic village is not sustainable and causes various environmental problems. For instance, the ecological diversity of this area is severely in danger by the expansion of touristic activities in Namak Abrud. Therefore, it is important to consider ecological diversity in the expansion plans of this village and other similar tourist destinations.

In order to overcome some of these problems there have been few initiatives in recent years, including some development limits. For example the height of villas and their residential area is now limited in various parts of the village. There are also some camping restrictions and tourists are only allowed to use specified camping areas; this restriction is probably a good step toward preserving the trees and wildlife from camping activities. Although these initiatives are good steps toward sustainable tourism, but it is crystal clear that there should be more restrictions in order to preserve the environment in this tourist destination.

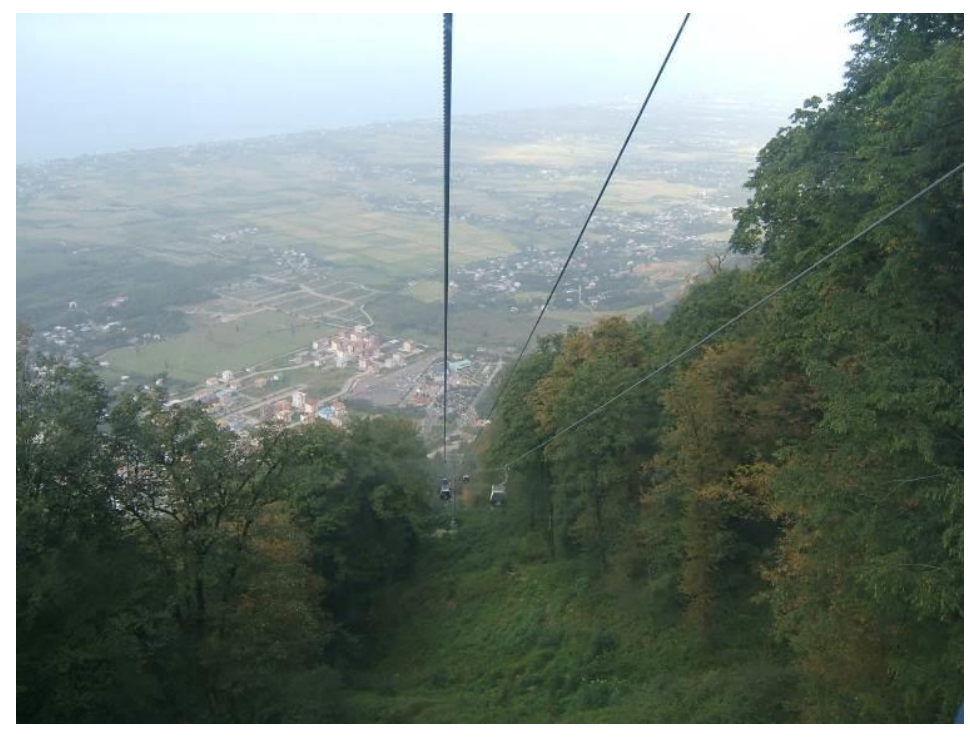

Figure 5. Namak Abrud has two cable car routes which transfer tourists from the main facilities in the village to the top of the mountain. It is evident in this photo that lots of trees have been cut in order to construct the cable car routes. 


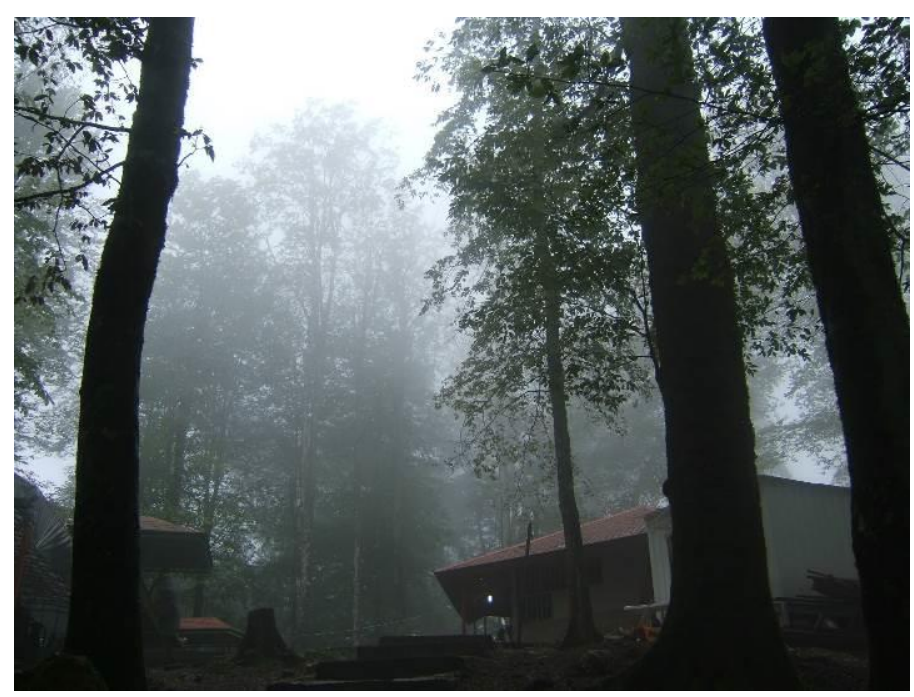

Figure 6. Numerous restaurants and coffee shops have been built on the top of the mountain to serve the tourists who visit Namak Abrud village. These restaurants and coffee shops have problems dealing with their wastewater and also significantly increase the amount of $\mathrm{CO}_{2}$ emission.



Figure 7. The photo depicts numerous villas, hotels, and restaurants built in Namak Abrud. The land which is now covered by these building used to be a forest in the past.

Lake Urmia is one of the largest saltwater lakes on earth with a length of approximately 140 kilometers (87 miles) and a width of approximately 55 kilometers (34 miles). The average depth of Lake Urmia is 16 meters (52 feet) and the lake is extremely salty. Due to the salty water the lake never freezes even in winter. The lake's water is rich in minerals and therefore it is used for treating skin diseases and rheumatoid disorders (Iranian Students' Tourism and 


\section{Macrothink}

Travelling Agency, 2011). In summer many tourists from around the world travel to West Azerbaijan province to see Lake Urmia and swim in it (Riasi, 2004). The lake size has significantly shrunk due to damming on the rivers that flow in to it, excessive pumping of ground waters for touristic activities and agriculture, and construction of a causeway and a bridge on the lake. In order to facilitate the transportation and increase the number of tourists visiting the lake, a causeway and a bridge where constructed on Lake Urmia. Environmentalists repeatedly warned that the construction of the causeway will lead to faster drying of Lake Urmia but construction of the causeway continued and it was opened in 2008. Lake Urmia is an example of unsustainable expansion of tourism industry. One of the potential solutions which have been proposed for solving the environmental problems associated with this lake is to reduce the amount of water behind the dams and to not use the dams at full capacity. This will increase the amount of water flow into the Lake Urmia and will probably help to decrease the rate at which the lake is drying. Unfortunately it seems almost impossible to undo the adverse effects of the causeway, but controlling the water reserves behind the dams is a more feasible solution for this issue.

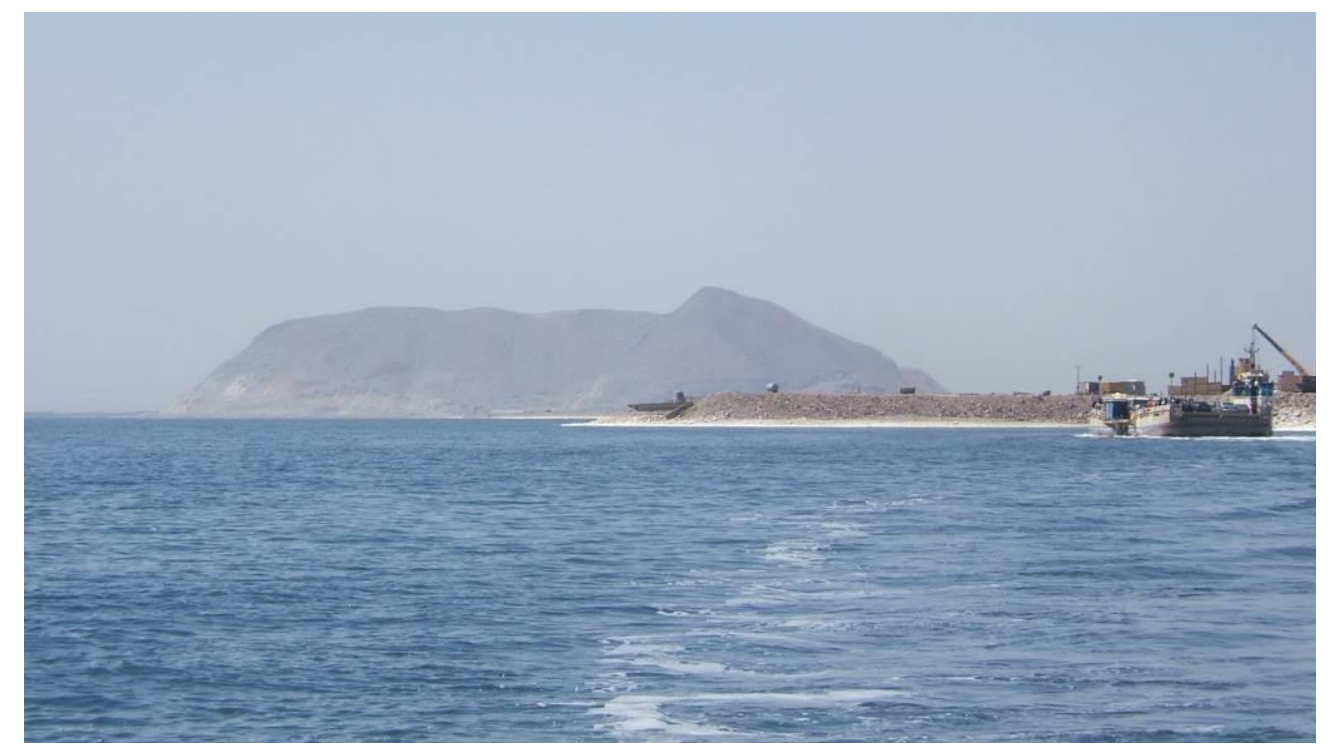

Figure 8 . The causeway built on Lake Urmia increased the salinity of water and contributed to faster drying of Lake Urmia. 


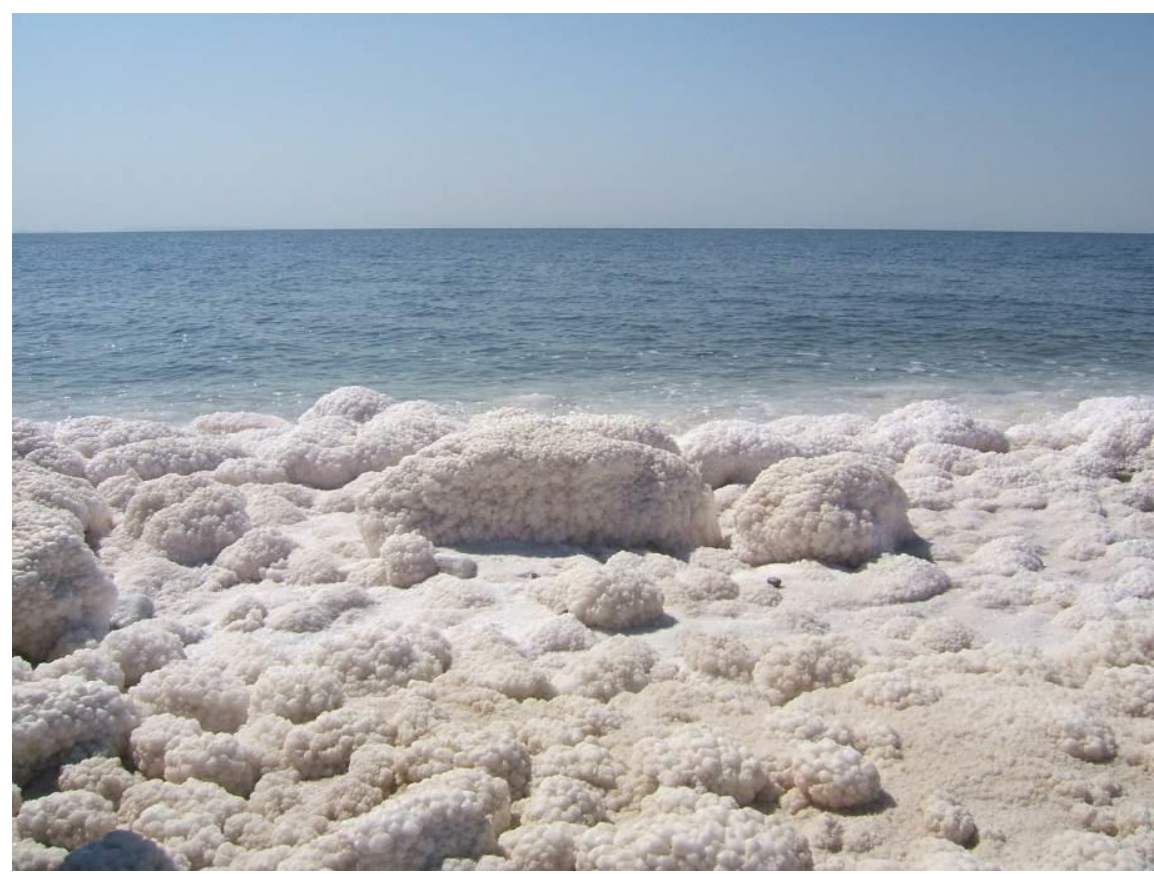

Figure 9. Salt rocks on the side of the causeway which is built over Lake Urmia.

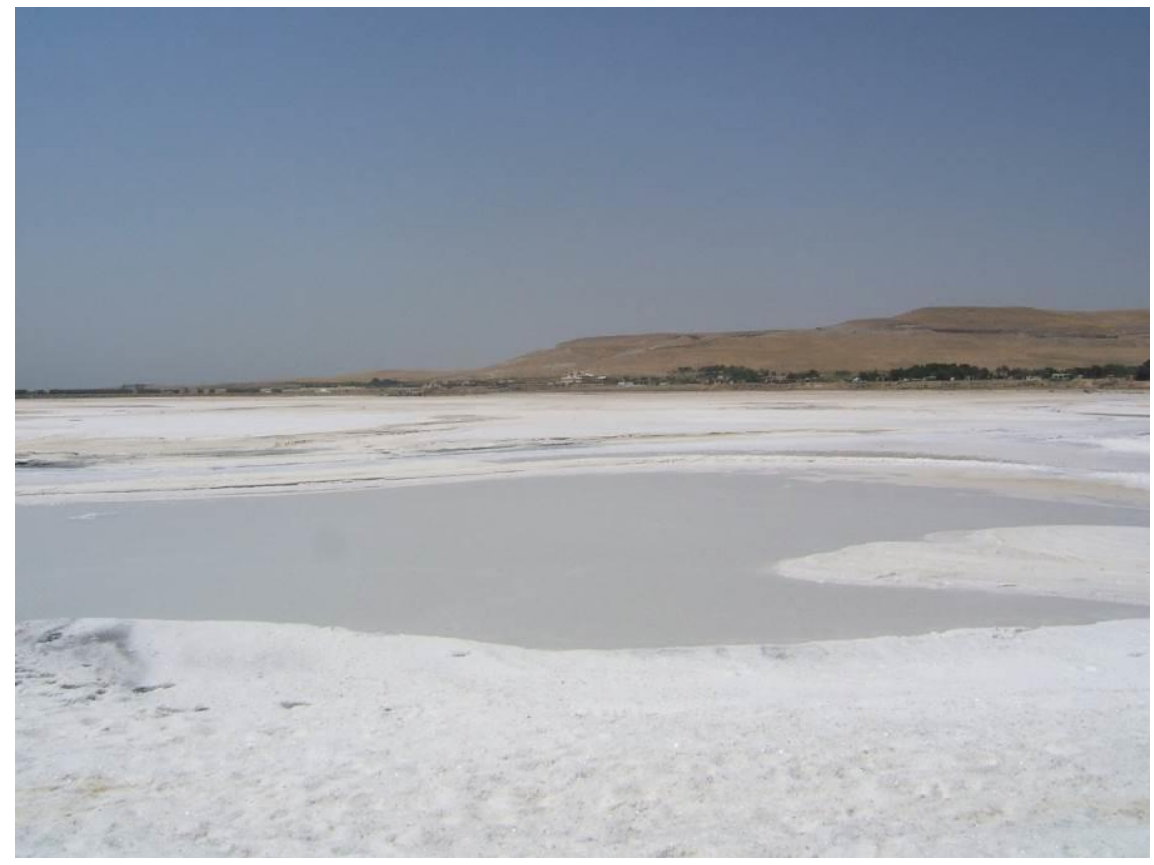

Figure 10. Large parts of Lake Urmia have been completely dried in recent years. The dried areas are filled with salt.

\section{Tourism Industry in Turkey}

According to the World Travel \& Tourism Council (WTTC) (2015b), the direct contribution of travel and tourism industry to Turkey's GDP was TRY 82.1 billion (approximately USD 37.6 billion) (4.7\% of total GDP) in 2014 and it is expected to rise to TRY 131.8 billion (approximately USD 60.5 billion) (4.7\% of total GDP) by 2025 . The total contribution of travel and tourism industry to Turkey's GDP was TRY 209.6 billion (approximately USD 


\section{Al Macrothink}

95.8 billion) (12\% of GDP) in 2014. Also in 2014, the travel and tourism industry directly supported 580000 jobs ( $2.2 \%$ of total employment) in Turkey which is expected to rise to 915000 jobs (2.9\% of total employment) by 2025 (WTTC, 2015b).

One of the top tourist destinations in Turkey is Istanbul. Istanbul has become an attractive destination for tourists in recent years and the number of tourists visiting this city has been increasing every year. According to Master Card Global Destination Cities Index (Hedrick-Wong \& Choong, 2015) Istanbul is the world's fifth destination city with 12.56 million international visitors expected in 2015. In the 2015 ranking, Istanbul moved from seventh to fifth rank which indicates that tourism industry is expanding in this city. Like many other cities of the world, there are some examples of unsustainable expansion of tourism industry in Istanbul. Building tramway and metro very close to tourist attractions is one of these examples, because the vibrations caused by trams and underground trains may have adverse effects on historical buildings. Another example of unsustainable expansion of tourism industry in this city is the increasing number of food carts and restaurants near historical buildings, particularly the Sultan Ahmed Mosque and Hagia Sophia. Food carts and restaurants produce a lot of smoke and increase $\mathrm{CO}_{2}$ emission which can be destructive for the nearby historical buildings. Turkey urgently needs to develop a strategy for sustainable development and one of the first steps toward developing this strategy is to study the effects of climate change in Turkey (Hurriyet Daily News, 2013). It is very important to consider the sustainable development of tourism industry when formulating these strategies.

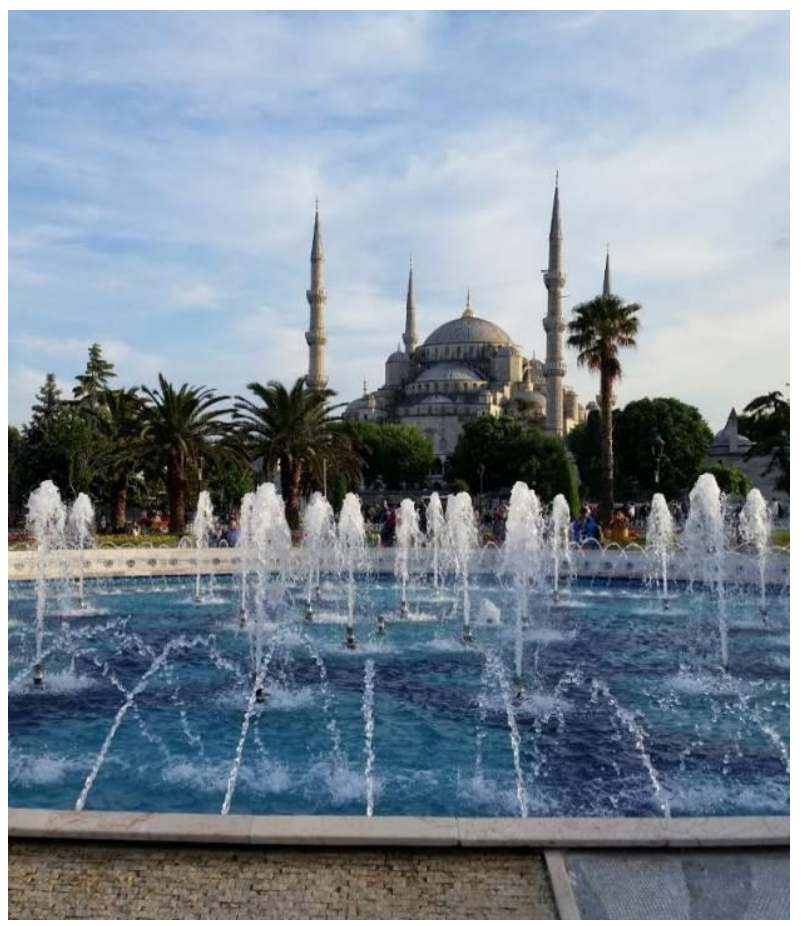

Figure 11. Sultan Ahmed Mosque which is also known as Blue Mosque was built between 1609 and 1616 AD. The mosque has one big dome, six minarets, and eight secondary domes. The design of the mosque is a mixture of Islamic architecture and Byzantine architecture. There are lots of food carts and restaurants near this building which create large amount of smoke and can harm the building. 


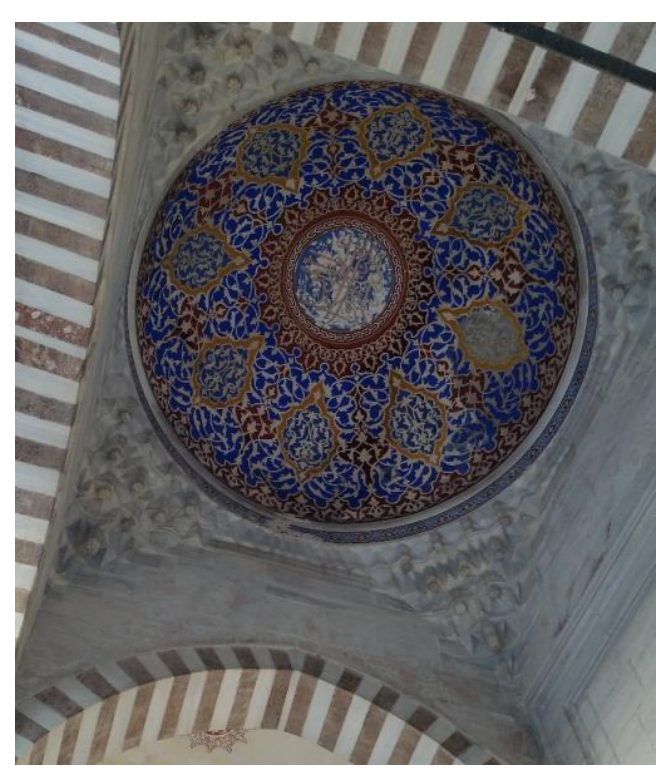

Figure 12. The beautiful architecture of Sultan Ahmed Mosque attracts many tourists to Istanbul every year.

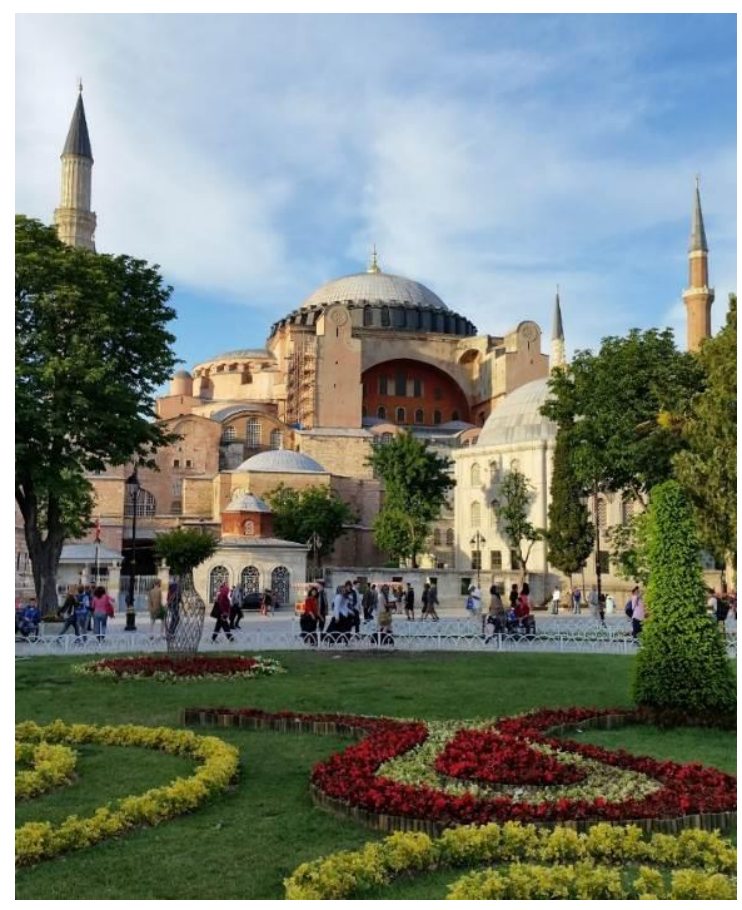

Figure 13. Hagia Sophia was built in $537 \mathrm{AD}$ and is one of the most famous tourist attractions of Istanbul. Hagia Sophia was initially used as a church and then transformed into a mosque, it is currently a museum. Hagia Sophia is an example of Byzantine architecture. There is a tramway very close to Hagia Sophia and its vibrations might have destructive effects on this historical building. 


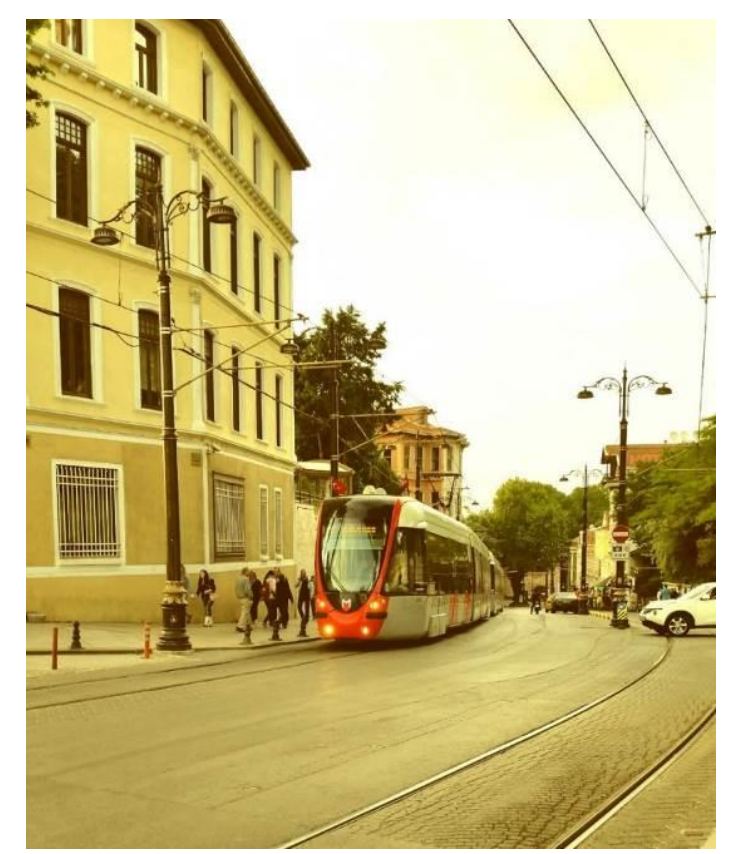

Figure 14. A large network of trams operates in Istanbul. The tram in this picture operates very close to Hagia Sophia and its vibrations might be destructive for the building. Although tramways help tourists to visit different parts of the city easily, fast, and at a cheap price, but they might have adverse effects on historic sites.

\section{Tourism Industry in the United Arab Emirates}

According to the World Travel \& Tourism Council (WTTC) (2015c), the direct contribution of travel and tourism industry to UAE's GDP was AED 61.6 billion (approximately USD 16.8 billion) (4.1\% of total GDP) in 2014 and it is expected to rise to AED 96.9 billion (approximately USD 26.4 billion) (4.5\% of total GDP) by 2025 . The total contribution of travel and tourism industry to UAE's GDP was AED 126.7 billion (approximately USD 34.5 billion) (8.4\% of GDP) in 2014. Also in 2014, the travel and tourism industry directly supported 307000 jobs (5.4\% of total employment) in UAE which is expected to rise to 420000 jobs (6.2\% of total employment) by 2025 (WTTC, 2015c).

One of the top tourist destinations in UAE is Dubai. Dubai is famous for its sky scrapers, shopping malls, beaches, and desert safari tours. According to Master Card Global Destination Cities Index (Hedrick-Wong \& Choong, 2015) Dubai is the world's fourth destination city with 14.26 million international visitors expected in 2015. Although the tourism industry has been expanding at phenomenal rates in Dubai, but some of these expansions are not in line with sustainable tourism requirements. For instance the desert safari tours which have been growing extensively in recent years, can potentially harm the environment. Particularly these safari tours can have adverse effects on desert animals and plants. Sustainable tourism is also tightly linked to the concept of sustainable mobility (Høyer, 2000). The majority of tourism's $\mathrm{CO}_{2}$ comes from transportation (around 72 percent) (Peeters $\&$ Dubois, 2010) and aviation accounts for more than half of the transportation $\mathrm{CO}_{2}$ emissions. Also since $\mathrm{CO}_{2}$ emissions from aviation are made at high altitude, their negative 


\section{Macrothink}

effect on climate is amplified (Gössling et al., 2010). Since the majority of tourists who visit Dubai use air transportation, expansion of tourism industry in this city can have severe adverse effects on climate. The construction of artificial islands is also another example of unsustainable expansion of tourism industry in Dubai. Constructing these islands will definitely affect the ecosystem of the Persian Gulf and after the islands will be inhabited they will probably cause more environmental damages. In 2014, Dubai courts launched an initiative called "Together to Protect the Environment" in order to preserve the natural resources and to achieve sustainable development (WAM, 2014). Hopefully this initiative will help to achieve environmental sustainability in tourism industry and other industries.

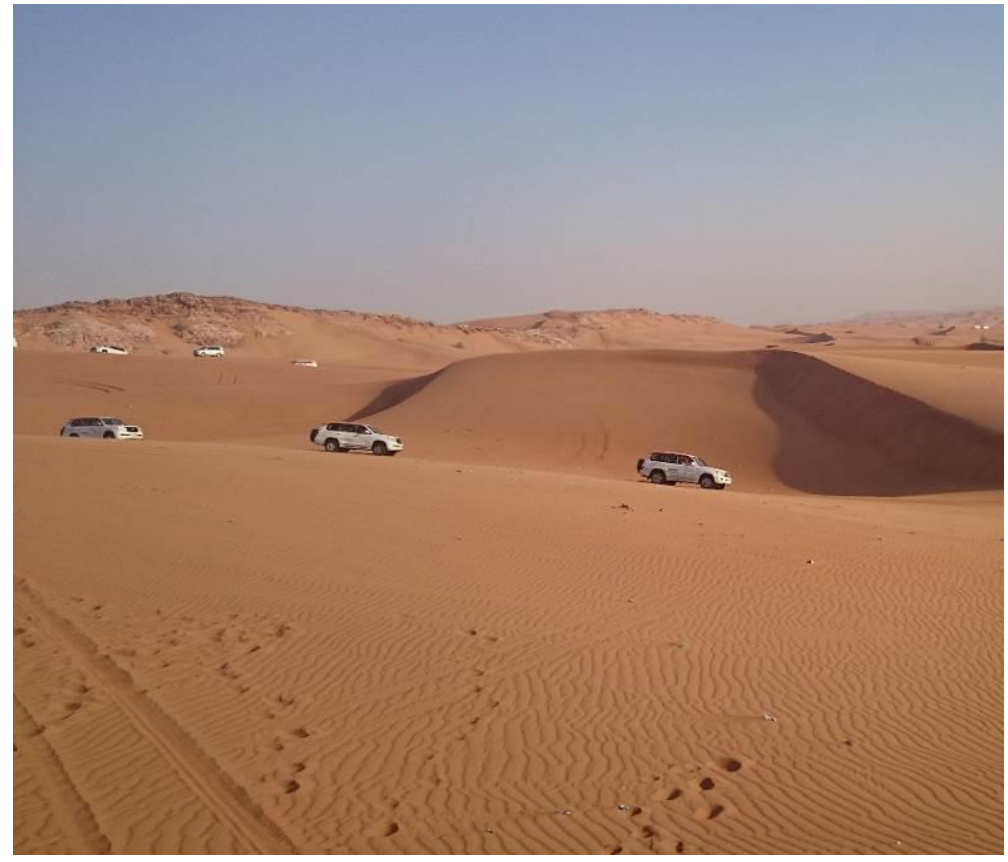

Figure 15. Desert safari tours near Dubai. Expansion of these tours can cause environmental damages to desert animals and plants. 


\section{Macrothink

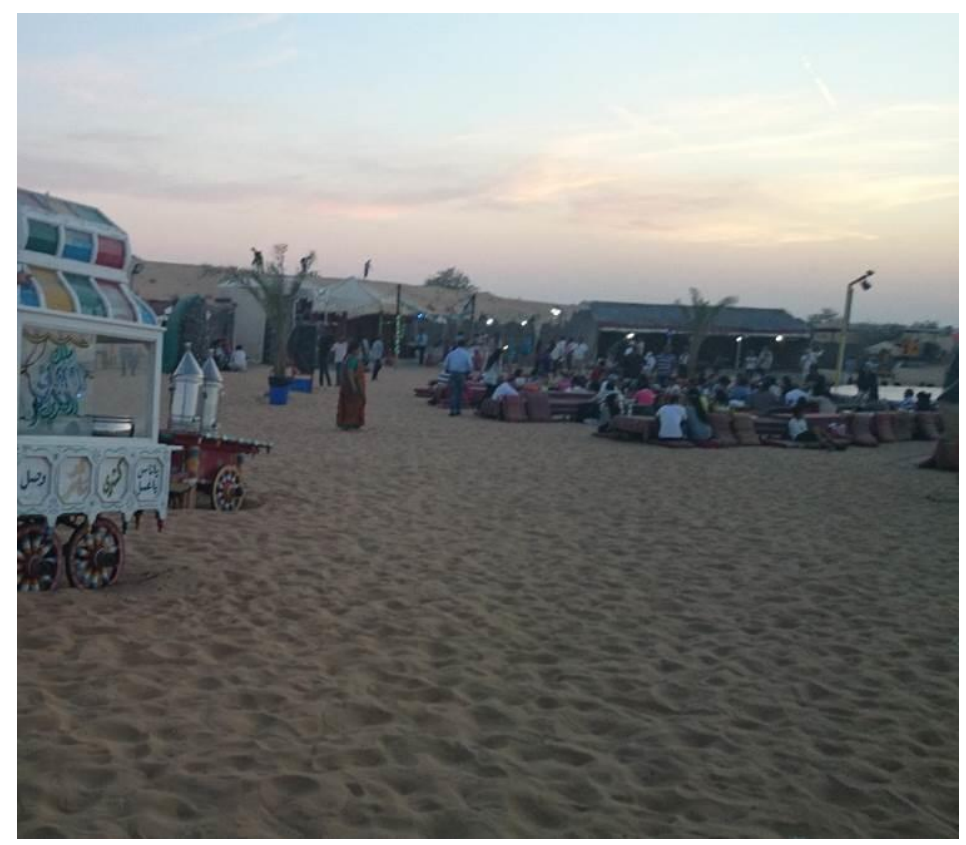

Figure 16. Most desert safari tours offer buffet dining, sand skiing, and camel riding. These activities can also increase the rate of environmental destruction to the desert.

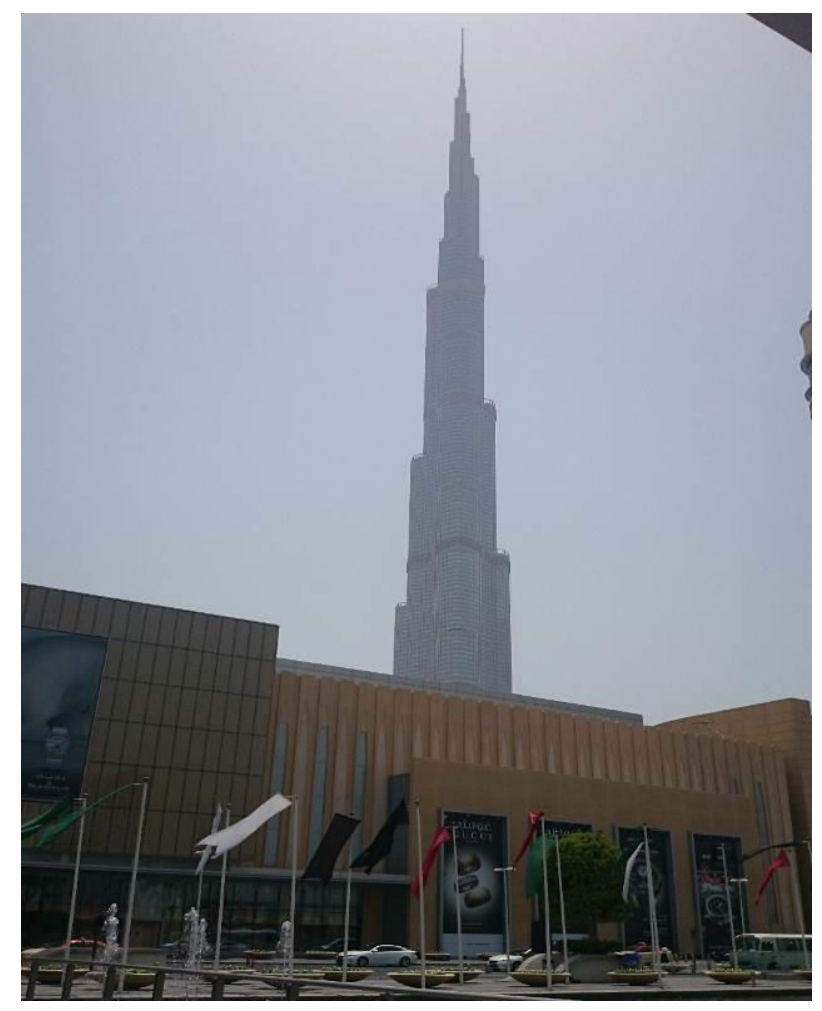

Figure 17. Burj Khalifa is the world's tallest building since 2010 with a height of 829.8 meters (2,722 feet). The nearby Dubai Mall which was opened in 2009 is the world's largest shopping mall by total area. In addition to more than 1200 shops, there is also an ice rink and an aquarium in this mall. 


\section{Macrothink}

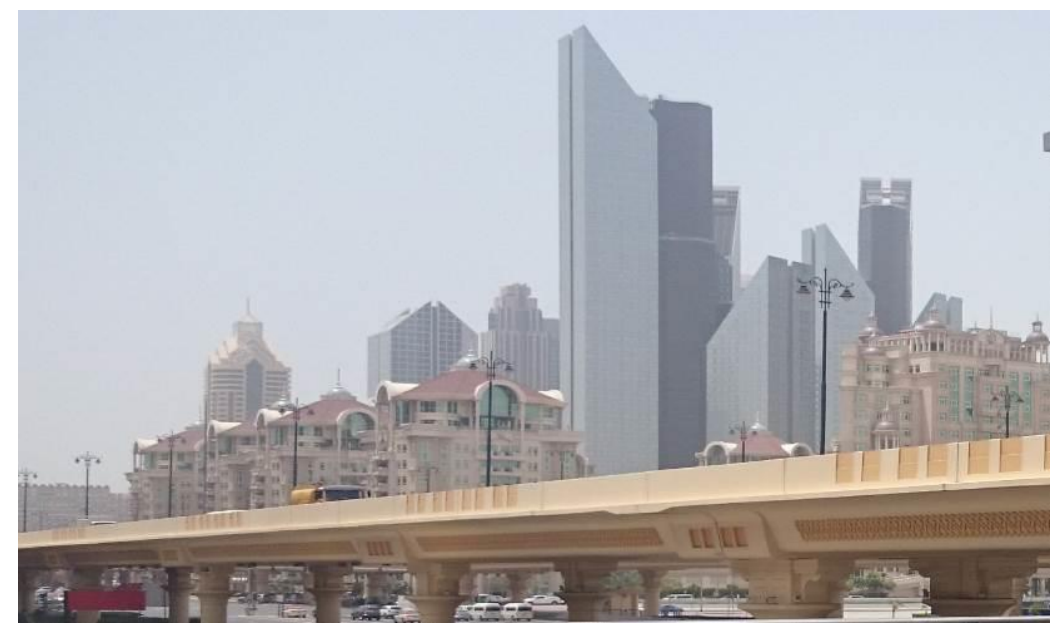

Figure 18. According to Emporis (2015), Dubai ranks fifth based on the number of tall buildings and skyscrapers after Hong-Kong, New York City, Tokyo and Chicago. There are currently 253 skyscrapers in Dubai (Emporis, 2015). The high rate of construction of new buildings in Dubai can cause environmental problems.

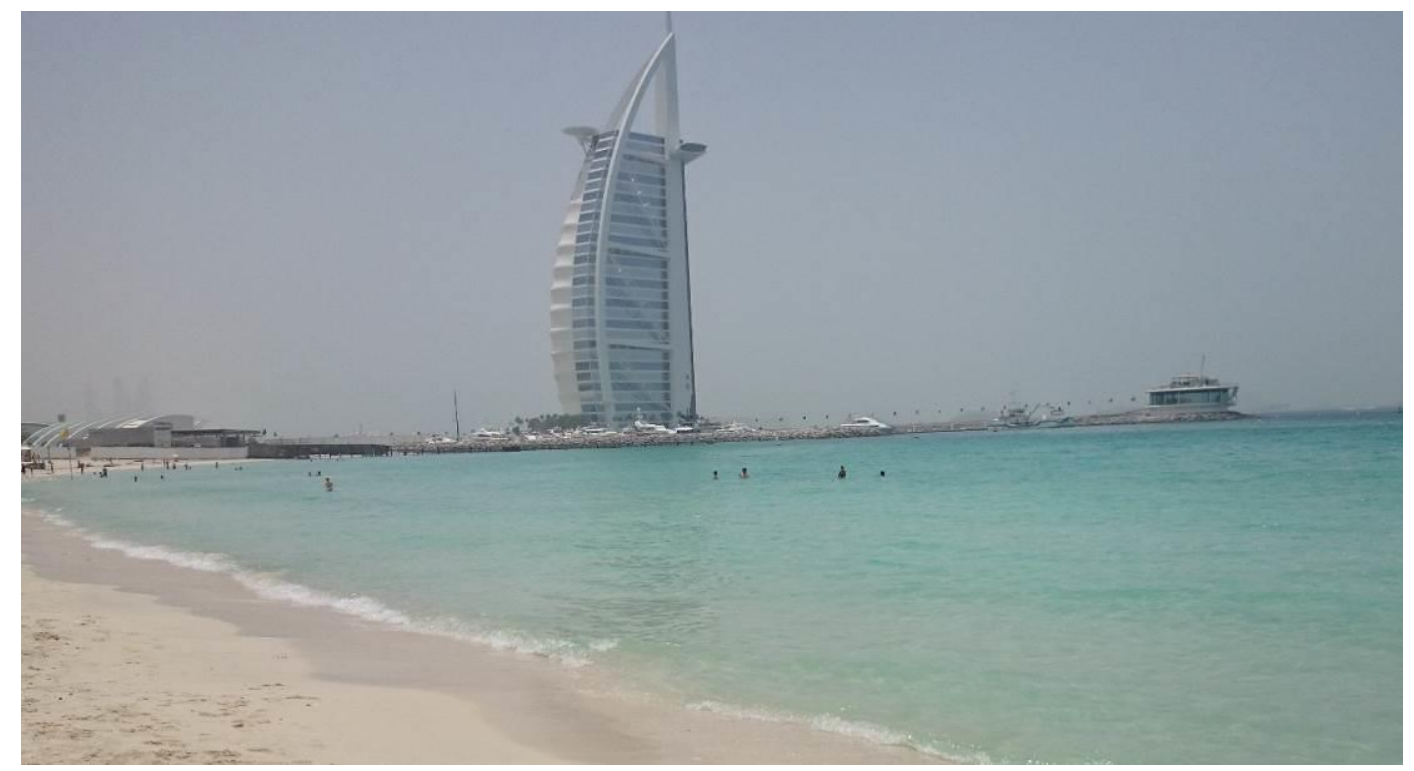

Figure 19. Burj Al Arab is the world's only 7 star hotel which was opened in 1999. The Hotel is 321 meters (1053 feet) tall and has 56 floors. The hotel is built on an artificial island.

\section{Conclusions}

In this paper we introduced various examples of unsustainable expansion of tourism industry in three Middle Eastern countries (Iran, Turkey, and the UAE). It is clear that the expansion of tourism without paying attention to sustainability issues can cause significant damages to the environment and even to the tourist attractions. Therefore, all countries should take sustainability issues into account when deciding about the expansion and development of the tourism industry. It is important to note that some of the problems which we mentioned in this article regarding the increasing amount of tourist traffic can relate to development in general. For instance in many developing countries without strong tourism industry we can 
still observe some of these issues. But the important point is that the tourism industry can make these problems more severe and the mentioned problems are more evident and detrimental to the environment in areas with extensive tourism activities.

According to Butler (1991) there are many prerequisites in order to have sustainable development in tourism industry, including pro-active planning, coordination of policies, education of all parties involved, limitations on growth, and commitment to long-term perspective. Sustainable tourism is an important component of sustainable development which should be encouraged in order to have a better world.

\section{References}

Amiri Aghdaie, S. F., Seidi, M., \& Riasi, A. (2012). Identifying the Barriers to Iran's Saffron Export by Using Porter's Diamond Model. International Journal of Marketing Studies, 4(5), 129-138. http://dx.doi.org/10.5539/ijms.v4n5p129

Balmford, A., Bruner, A., Cooper, P., Costanza, R., Farber, S., \& Green, R. E., et al. (2002). Economic reasons for conserving wild nature. Science, 297(5583), 950-953. http://dx.doi.org/10.1126/science.1073947

Butler, R. W. (1991). Tourism, environment, and sustainable development. Environmental conservation, 18(3), 201-209. http://dx.doi.org/10.1017/S0376892900022104

Das, M., \& Chatterjee, B. (2015). Ecotourism: A panacea or a predicament?.Tourism Management Perspectives, 14, 3-16. http://dx.doi.org/10.1016/j.tmp.2015.01.002

Emporis (2015). Cities with the most skyscrapers. Retrieved November 8, 2015, from http://www.emporis.com/statistics/most-skyscraper-cities-worldwide

Gössling, S., Hall, C. M., Peeters, P., \& Scott, D. (2010). The future of tourism: Can tourism growth and climate policy be reconciled? A mitigation perspective. Tourism Recreation Research, 35(2), 119-130. http://dx.doi.org/10.1080/02508281.2010.11081628

Hamshahri Newspaper (2015). The disappearance of tourists' memories by destruction of Greek Ship. Retrieved November 8, 2015, from http://www.hamshahrionline.ir/details/289154/Travel/tourism

Hedrick-Wong, Y., \& Choong, D. (2015). Master Card 2015 Global Destination Cities Index, Master Card.

Holden, A. (2003). In need of new environmental ethics for tourism. Annals of Tourism Research, 30(1), 94-108. http://dx.doi.org/10.1016/S0160-7383(02)00030-0

Holland, J., Burian, M., \& Dixey, L. (2003). Tourism in poor rural areas. PPT working paper no. 12. ODI, IIED, ICRT. Retrieved August 25, 2013, from http://www.odi.org.uk/RPEG/PPT/WP12

Høyer, K. G. (2000). Sustainable tourism or sustainable mobility? The Norwegian case. $\begin{array}{lllll}\text { Journal of } \quad \text { Sustainable } & \text { 147-160. }\end{array}$ http://dx.doi.org/10.1080/09669580008667354 
Hurriyet Daily News (2013). Turkey urgently needs a sustainable development strategy.

$\begin{array}{llll}\text { Retrieved November } & \text { 8, 2015, from }\end{array}$

http://www.hurriyetdailynews.com/turkey-urgently-needs-a-sustainable-development-strategy .aspx? pageID $=238 \& n I D=58064 \&$ NewsCatID $=338$

Iranian Students' Tourism and Travelling Agency (2011). Natural Attractions. Retrieved September 14, 2015, from http://istta.ir/nature.aspx?ID=935

Mihalic, T. (2000). Environmental management of a tourist destination: A factor of tourism competitiveness. Tourism Management, $\quad$ 21(1), http://dx.doi.org/10.1016/S0261-5177(99)00096-5

Neto, F. (2003, August). A new approach to sustainable tourism development: Moving beyond environmental protection. In Natural Resources Forum (Vol. 27, No. 3, pp. 212-222). Blackwell Publishing Ltd. http://dx.doi.org/10.1111/1477-8947.00056

Peeters, P., \& Dubois, G. (2010). Tourism travel under climate change mitigation constraints. Journal of Transport Geography, 18(3), 447-457. http://dx.doi.org/10.1016/j.jtrangeo.2009.09.003

Riasi, A. (2004). Introducing some of the most famous tourist attractions of Iran and the world, Mashhad: Sokhan Gostar Publication. http://dx.doi.org/10.13140/RG.2.1.1101.8088.

Riasi, A. (2015a). Barriers to international supply chain management in Iranian flower industry. Management Science $\quad$ Letters, 563-368. http://dx.doi.org/10.5267/j.ms1.2015.2.005

Riasi, A. (2015b). Competitive Advantages of Shadow Banking Industry: An Analysis Using Porter Diamond Model. Business Management and Strategy, 6(2), 15-27. http://dx.doi.org/10.5296/bms.v6i2.8334

Riasi, A., \& Amiri Aghdaie, S. F. (2013). Effects of a Hypothetical Iranian Accession to the World Trade Organization on Iran's Flower Industry. Consilience: The Journal of Sustainable Development, 10(1), 99-110.

Riasi, A., \& Asadzadeh, N. (2015). The relationship between principals' reward power and their conflict management styles based on Thomas-Kilmann conflict mode instrument. Management Science Letters, 5(6), 611-618. http://dx.doi.org/10.5267/j.msl.2015.4.004

Riasi, A., \& Pourmiri, S. (2015). Effects of online marketing on Iranian ecotourism industry: Economic, sociological, and cultural aspects. Management Science Letters, 5(10), 915-926. http://dx.doi.org/10.5267/j.msl.2015.8.005

Sharpley, R. (2000). Tourism and sustainable development. Exploring the theoretical divide. Journal of Sustainable Tourism, 8(1), 1-19. http://dx.doi.org/10.1080/09669580008667346

Tepelus, C. M., \& Cordobci, R. C. (2005). Recognition schemes in tourism-Fromeco to sustainability? Journal of Cleaner Production, 13(2), 135-140. http://dx.doi.org/10.1016/j.jclepro.2003.12.015 


\section{Macrothink}

Environmental Management and Sustainable Development

ISSN 2164-7682 2016, Vol. 5, No. 1

The International Ecotourism Society (TIES) (1990). What is Ecotourism? Retrieved September 2, 2013, from http://www.ecotourism.org/what-is-ecotourism

UNEP \& UNWTO, (2005). Making Tourism More Sustainable - A Guide for Policy Makers, 11-12.

Walter, P. G., \& Reimer, J. K. (2012). The "ecotourism curriculum" and visitor learning in community-based ecotourism: Case studies from Thailand and Cambodia. Asia Pacific Journal of Tourism Research, 17(5), 551-561. http://dx.doi.org/10.1080/10941665.2011.627930

WAM (2014). Dubai Courts launches "Together To Protect The Environment" initiative. $\begin{array}{llll}\text { Retrieved November } & \text { 8, 2015, from }\end{array}$ https://www.wam.ae/en/news/general/1395273680943.html

WTTC (2015b). Travel \& Tourism: Economic Impact 2015 Iran. London: World Travel \& Tourism Council.

WTTC (2015b). Travel \& Tourism: Economic Impact 2015 Turkey. London: World Travel \& Tourism Council.

WTTC (2015c). Travel \& Tourism: Economic Impact 2015 United Arab Emirates. London: World Travel \& Tourism Council.

\section{Copyright Disclaimer}

Copyright for this article is retained by the author(s), with first publication rights granted to the journal.

This is an open-access article distributed under the terms and conditions of the Creative Commons Attribution license (http://creativecommons.org/licenses/by/3.0/). 